\title{
Large tsunamis reset growth of massive corals
}

\author{
Kazuhisa Goto ${ }^{1 *} \mathbb{D}$, Chuki Hongo ${ }^{2}$, Masashi Watanabe ${ }^{3}$, Keitaro Miyazawa ${ }^{3}$ and Akifumi Hisamatsu ${ }^{3}$
}

\begin{abstract}
Corals at Ishigaki Island, Japan, are characterized by their high species diversity. Not only are they struck by storm waves generated annually by typhoons, the corals, especially the massive ones, in the fringing reef were buffeted by huge tsunami waves with a run-up height of ca. $30 \mathrm{~m}$ in 1771 Meiwa tsunami and its predecessors at few hundredyear intervals. We present field survey and numerical results demonstrating that such near-field large tsunamis could have reset the growth of massive corals, a phenomenon which large typhoons have not caused. Our field survey revealed that the massive corals in the lagoon are not attached to the bedrock but are instead located on the sandy sea bottom. Therefore, those are movable of sufficiently large wave inundated in the lagoon. Our numerical results further showed that the maximum velocity of the tsunami at the reef edge, calculable as $<21.2 \mathrm{~m} / \mathrm{s}$ at the study area, is still high in the shallow lagoon, perhaps generating sufficiently strong hydrodynamic force to devastate the massive corals in the shallow lagoon entirely, as well as some presumed damages on tabular and branching corals on the reef crest and reef slope. This numerical result is consistent with the observed fact that even a 9-m long Porites boulder (about 220 t) was cast ashore by the 1771 tsunami. The sizes of the presently living massive corals of Porites spp. are consistent with our hypothesis that they started to grow after the latest 1771 tsunami event. At the coral reefs of high tsunami-risk countries, severe destruction of corals by large tsunami waves should be considered for their growth history because, depending on the bathymetry, coral characteristics, and tsunami hydrodynamic features, tsunamis can radically alter coral habitats.
\end{abstract}

Keywords: Boulder, Coral, Disaster, Hazard, Ishigaki Island, Tsunami, Tsunami effects on coral, Coral boulder, Numerical modeling

\section{Introduction}

Physical perturbation of corals by extreme waves can generate a remarkably strong influence on marine ecosystems (Madin and Connolly 2006; Puotinen et al. 2016). Tsunami waves are extremely powerful, affecting coral communities. In fact, coral damage by tsunami waves, which includes whole or partial damage of corals by destruction, rotation, sedimentation of sands on corals, and local slides of reef slopes, has been reported in the case of the 2004 Indian Ocean tsunami (IOT) (e.g., Phuket Marine Biological Center (PMBC) 2005; Chavanich et al. 2008) and the 2009 South Pacific tsunami (McAdoo et al. 2011; Witt et al. 2011; Dilmen et al. 2015).

\footnotetext{
* Correspondence: goto@irides.tohoku.ac.jp

${ }^{1}$ International Research Institute of Disaster Science, Tohoku University, Aoba 468-1 Aramaki, Aoba-ku, Sendai 980-0845, Japan

Full list of author information is available at the end of the article
}

Coral damage is generally related to the place where the tsunami hydrodynamic forces strengthen (Goto and Imamura 2009; Kawamata et al. 2009), although the relation is unclear. For example, coral damage by the 2004IOT at the islands in Thailand was high in straits among the islands and at the northern and southern headlands of the respective islands (PMBC 2005), where the tsunami hydrodynamic forces are stronger (Kawamata et al. 2009). However, coral damage by the 2004IOT was generally low. Therefore, researchers who conducted studies after 2004IOT have tended to conclude that the tsunami impact effects on coral communities are limited (Baird et al. 2005; Morri et al. 2015).

However, because few case studies have been reported, one must not underestimate the tsunami effects on corals' ability to inhabit an area. Huge tsunami waves are likely to have the capability of devastating coral communities depending on the nearby bathymetric features, 
coral characteristics, and related hydrodynamic forces. This possibility must be explored because tsunami waves might be able to change the coral habitability radically: they present a high risk to reef environments. In fact, huge coral boulders are well known to be cast ashore by tsunami waves (so-called tsunami boulders) and storm waves (e.g., Goto et al. 2010a, 2013; Atwater et al. 2017; Ramos et al. 2017; Hongo et al. 2018; Rixhon et al. 2018). These phenomena in turn indicate that large corals can be damaged by extreme wave events.

As one example, based on field observations and tsunami numerical modeling, we describe the possible catastrophic destruction of massive corals by the 1771 Meiwa tsunami, which struck the east coast of Ishigaki Island, Japan (Fig. 1a) (Goto et al. 2010a). Moreover, we discuss the effects of catastrophic but infrequent tsunami wave strikes on coral communities.

\section{Study area}

Ishigaki Island is encircled by a $<1.5 \mathrm{~km}$ wide fringing reef (Hongo and Kayanne 2009). Our study area, Ibaruma reef, has a fringing reef 500-900 m offshore (Fig. 1b, c, Goto et al. 2010b). The coral reef is divisible into a reef flat and reef slope (Fig. 1c): the former is further classified into a shallow lagoon that is up to $5 \mathrm{~m}$ deep and a reef crest (Hongo and Kayanne 2009). During low tide, the reef crest lies exposed above the ocean surface. The reef slope is steep, with approx. 1/10 inclination (Fig. 1c). The reef is well-developed along the Pacific windward coast rather than leeward areas (Ministry of the Environment and the Japanese Coral Reef Society 2004). Few typhoons annually pass close to the Ishigaki Island, and the coral reef in the study area is frequently affected by the storm waves (e.g., Hongo et al. 2012).

Forty-four coral species are found between the shoreline and $1580 \mathrm{~m}$ from the shoreline, characterized by a

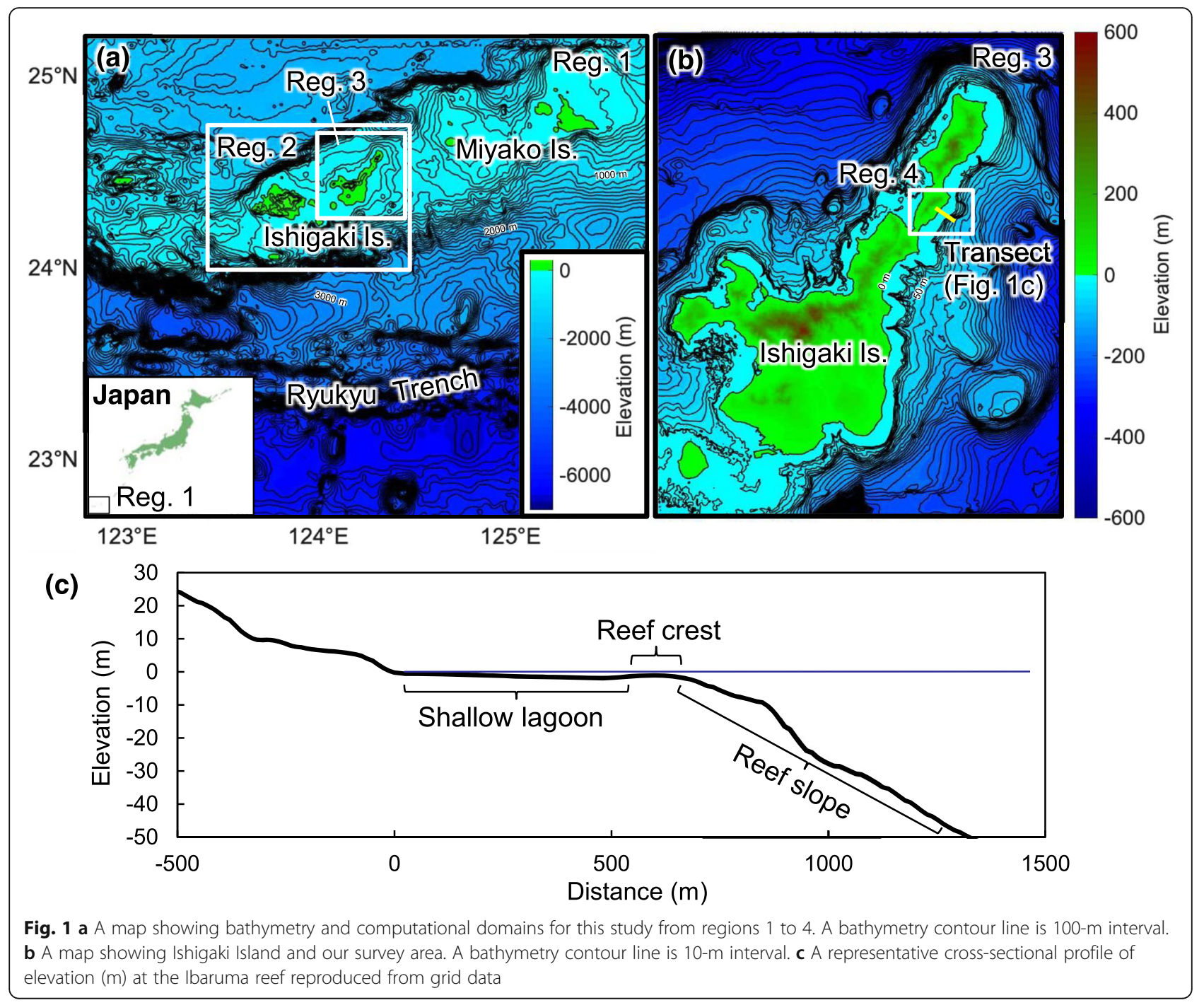


water depth of $20 \mathrm{~m}$, at Ibaruma reef (Hongo and Kayanne 2010). Massive corals, tabular corals, and branching corals represent $33 \%, 10 \%$, and $6 \%$ of the total coverage, respectively. Other growth forms of coral (e.g., encrusting and sub-massive) are also observed in the reef. The shallow lagoon is dominated by massive corals (e.g., Porites spp.). Tabular corals (e.g., Acropora spp.) are mainly found from the reef crest to the upper reef slope. Branching corals (e.g., Montipora spp. and Acropora spp.) are widely distributed from the shallow lagoon to the reef crest. Encrusting corals (e.g., Pachyseris spp.) occupy the lower reef slope.

The 1771 Meiwa tsunami struck Ishigaki Island although the epicenter causing this tsunami has not been revealed. Historical documents revealed that the run-up heights were estimated as up to about $30 \mathrm{~m}$ at the southeast coast of Ishigaki Island (Goto et al. 2010a). Displacement of Porites boulders by the tsunami, which were originally located in the shallow lagoon, was reported along the shoreline of the east coast including the Ibaruma reef (Kawana and Nakata 1994; Suzuki et al. 2008; Goto et al. 2010a, 2010b, 2013; Araoka et al. 2013). Despite their mass, the exceedingly heavy boulders are scattered well beyond the transport limit for storm waves estimated by Goto et al. (2010b, 2013). Watanabe et al. (2016) further supported the reports of their tsunami origin using numerical modeling results, demonstrating that their size and spatial distributions are not explainable by typhoon-generated storm waves. Moreover, according to the ${ }^{14} \mathrm{C}$ age results, most of them were deposited by the 1771 Meiwa tsunami although some of the boulders might have been deposited by earlier tsunamis (Suzuki et al. 2008; Araoka et al. 2013). Recent studies estimated tsunami recurrence intervals of about 150-400 years based on tsunami boulders (Araoka et al. 2013) and about 600 years based on fine-grained tsunami deposits (Ando et al. 2018; Kitamura et al. 2018a, 2018b). The largest Porites boulder of the 1771 Meiwa tsunami origin, locally called a Bari-ishi boulder (Fig. 2a, Bari-ishi means a stone split into pieces in Japanese), is $129 \mathrm{~m}^{3}$ $(9.0 \times 7.0 \times 3.9 \mathrm{~m})$, weighing an estimated $216 \mathrm{t}$ (Goto et al. 2010b; Araoka et al. 2013).

\section{Methods/Experimental}

Since the massive corals grow annually with a nearly constant rate (e.g., Araoka et al. 2010), their size distribution allows us to test whether these massive corals started to grow after the 1771 Meiwa tsunami. We therefore took non-destructive underwater measurements of the size and spatial distributions of 85 massive corals of Porites spp. using a scale and handy global positioning system (GPS) in the Ibaruma reef mainly in August 2011. We measured massive corals having a long axis greater than approx. $2 \mathrm{~m}$ (Table 1 ).


Fig. 2 a The largest Bari-ishi boulder that was deposited by the 1771 Meiwa tsunami at the Ibaruma reef (Goto et al. 2010b). b An image of typical massive living coral in the lagoon

Results reported by Miyazawa et al. (2012) provide the basis of our numerical modeling of the tsunami inundation. A linear equation is adopted to calculate propagation of the 1771 Meiwa tsunami in the wider regions. A nonlinear equation in a rectangular coordinate system is used to calculate the tsunami propagation in the reef and the surrounding regions (Goto et al. 1997), and the bottom friction is allowed (Kotani et al. 1998). For the calculation, a nested grid system is created across four regions (Figs. 1 and 3a). Spatial grid sizes of the respective regions are 300 $\mathrm{m}, 100 \mathrm{~m}, 50 \mathrm{~m}$, and $10 \mathrm{~m}$ for regions 1, 2, 3, and 4, respectively (after Miyazawa et al. 2012). Manning's friction coefficient is based on the land use map. The calculation time is $45 \mathrm{~min}$ after tsunami generation, which is a sufficient time to evaluate the tsunami effects on the reef (Miyazawa et al. 2012). It should be noted that bathymetric data in the lagoon are not well reproduced because taking such measurements is difficult inside the lagoon and future update of the bathymetric data in the lagoon is required.

Some source models are proposed for the 1771 Meiwa tsunami. Imamura et al. (2008) and Miyazawa et al. (2012) proposed an intraplate fault plus landslide model. 
Table 1 Locations and three dimensions of measured living massive corals

\begin{tabular}{|c|c|c|c|c|c|}
\hline No. & Latitude $\left({ }^{\circ} \mathrm{N}\right)$ & Longitude $\left({ }^{\circ} \mathrm{E}\right)$ & Long axis $(\mathrm{cm})$ & Short axis $(\mathrm{cm})$ & Height $(\mathrm{cm})$ \\
\hline 1 & 24.51656 & 124.29756 & 340 & 330 & 130 \\
\hline 2 & 24.51655 & 124.29747 & 240 & 140 & 115 \\
\hline 3 & 24.51655 & 124.29743 & 380 & 270 & 165 \\
\hline 4 & 24.51599 & 124.29714 & 315 & 265 & 135 \\
\hline 5 & 24.51557 & 124.29736 & 345 & 325 & 140 \\
\hline 6 & 24.51574 & 124.2974 & 230 & 220 & 120 \\
\hline 7 & 24.51589 & 124.29751 & 195 & 150 & 130 \\
\hline 8 & 24.51493 & 124.29794 & 330 & 330 & 250 \\
\hline 9 & 24.51469 & 124.29806 & 410 & 390 & 200 \\
\hline 10 & 24.51466 & 124.29796 & 370 & 310 & 170 \\
\hline 11 & 24.51466 & 124.29802 & 340 & 265 & 197 \\
\hline 12 & 24.51458 & 124.29829 & 455 & 395 & 280 \\
\hline 13 & 24.5146 & 124.29834 & 330 & 230 & 245 \\
\hline 14 & 24.51459 & 124.29828 & 250 & 200 & 90 \\
\hline 15 & 24.51457 & 124.29825 & 210 & 190 & 175 \\
\hline 16 & 24.51483 & 124.29823 & 340 & 220 & 80 \\
\hline 17 & 24.51464 & 124.29819 & 260 & 220 & 75 \\
\hline 18 & 24.5145 & 124.29846 & 390 & 350 & 285 \\
\hline 19 & 24.51479 & 124.29908 & 315 & 290 & 210 \\
\hline 20 & 24.51483 & 124.29903 & 440 & 430 & 242 \\
\hline 21 & 24.51501 & 124.299 & 300 & 300 & 196 \\
\hline 22 & 24.51501 & 124.299 & 370 & 340 & 187 \\
\hline 23 & 24.51501 & 124.299 & 250 & 245 & 185 \\
\hline 24 & 24.51517 & 124.29877 & 235 & 200 & 129 \\
\hline 25 & 24.51518 & 124.29884 & 300 & 285 & 232 \\
\hline 26 & 24.51463 & 124.29982 & 430 & 365 & 228 \\
\hline 27 & 24.51465 & 124.29977 & 340 & 320 & 278 \\
\hline 28 & 24.51459 & 124.29979 & 490 & 410 & 265 \\
\hline 29 & 24.51462 & 124.29961 & 455 & 425 & 250 \\
\hline 30 & 24.51463 & 124.29958 & 550 & 410 & 248 \\
\hline 31 & 24.51464 & 124.29947 & 480 & 445 & 260 \\
\hline 32 & 24.5146 & 124.29935 & 440 & 385 & 250 \\
\hline 33 & 24.51452 & 124.29928 & 490 & 410 & 312 \\
\hline 34 & 24.51471 & 124.29922 & 430 & 360 & 198 \\
\hline 35 & 24.51394 & 124.29768 & 435 & 410 & 310 \\
\hline 36 & 24.5131 & 124.29748 & 310 & 250 & 175 \\
\hline 37 & 24.5131 & 124.29748 & 350 & 305 & 150 \\
\hline 38 & 24.51322 & 124.29745 & 305 & 300 & 185 \\
\hline 39 & 24.51318 & 124.29765 & 415 & 300 & 172 \\
\hline 40 & 24.51315 & 124.29773 & 290 & 265 & 213 \\
\hline 41 & 24.51012 & 124.29201 & 650 & 615 & 190 \\
\hline 42 & 24.51287 & 124.29357 & 340 & 240 & 130 \\
\hline 43 & 24.51266 & 124.29351 & 455 & 330 & 172 \\
\hline 44 & 24.51253 & 124.29349 & 225 & 180 & 155 \\
\hline
\end{tabular}


Table 1 Locations and three dimensions of measured living massive corals (Continued)

\begin{tabular}{|c|c|c|c|c|c|}
\hline No. & Latitude ( $\left.{ }^{\circ} \mathrm{N}\right)$ & Longitude $\left({ }^{\circ} \mathrm{E}\right)$ & Long axis $(\mathrm{cm})$ & Short axis (cm) & Height $(\mathrm{cm})$ \\
\hline 45 & 24.51262 & 124.29381 & 210 & 145 & 120 \\
\hline 46 & 24.51247 & 124.294 & 340 & 270 & 192 \\
\hline 47 & 24.51243 & 124.29408 & 350 & 280 & 190 \\
\hline 48 & 24.51231 & 124.29415 & 390 & 380 & 207 \\
\hline 49 & 24.51228 & 124.29416 & 280 & 240 & 185 \\
\hline 50 & 24.51223 & 124.29438 & 270 & 190 & 142 \\
\hline 51 & 24.51212 & 124.29429 & 445 & 400 & 102 \\
\hline 52 & 24.5122 & 124.29443 & 315 & 240 & 145 \\
\hline 53 & 24.51245 & 124.29459 & 380 & 375 & 135 \\
\hline 54 & 24.51261 & 124.29461 & 365 & 345 & 160 \\
\hline 55 & 24.51252 & 124.29506 & 425 & 415 & 118 \\
\hline 56 & 24.51238 & 124.2949 & 360 & 270 & 190 \\
\hline 57 & 24.51227 & 124.29513 & 490 & 460 & 210 \\
\hline 58 & 24.51225 & 124.29521 & 285 & 150 & 180 \\
\hline 59 & 24.51176 & 124.29476 & 360 & 340 & 172 \\
\hline 60 & 24.51189 & 124.29476 & 350 & 200 & 178 \\
\hline 61 & 24.51187 & 124.29477 & 265 & 190 & 145 \\
\hline 62 & 24.51244 & 124.29581 & 465 & 420 & 224 \\
\hline 63 & 24.51242 & 124.29587 & 450 & 370 & 160 \\
\hline 64 & 24.51242 & 124.29587 & 350 & 310 & 125 \\
\hline 65 & 24.51242 & 124.29595 & 330 & 295 & 143 \\
\hline 66 & 24.51227 & 124.29598 & 300 & 260 & 132 \\
\hline 67 & 24.5122 & 124.29593 & 345 & 300 & 115 \\
\hline 68 & 24.51062 & 124.29468 & 525 & 400 & 195 \\
\hline 69 & 24.51067 & 124.29466 & 355 & 335 & 190 \\
\hline 70 & 24.51097 & 124.29337 & 270 & 200 & 150 \\
\hline 71 & 24.51109 & 124.29347 & 235 & 220 & 195 \\
\hline 72 & 24.51106 & 124.29348 & 425 & 375 & 190 \\
\hline 73 & 24.51091 & 124.29326 & 235 & 190 & 135 \\
\hline 74 & 24.51088 & 124.29315 & 320 & 265 & 225 \\
\hline 75 & 24.51085 & 124.29319 & 180 & 170 & 135 \\
\hline 76 & 24.51078 & 124.29317 & 400 & 380 & 173 \\
\hline 77 & 24.51053 & 124.29333 & 350 & 310 & 170 \\
\hline 78 & 24.51078 & 124.29328 & 210 & 165 & 125 \\
\hline 79 & 24.51078 & 124.29328 & 250 & 175 & 135 \\
\hline 80 & 24.51078 & 124.29328 & 200 & 190 & 133 \\
\hline 81 & 24.51083 & 124.29299 & 420 & 385 & 165 \\
\hline 82 & 24.51088 & 124.29292 & 340 & 280 & 160 \\
\hline 83 & 24.51087 & 124.29251 & 275 & 225 & 160 \\
\hline 84 & 24.511 & 124.29203 & 330 & 265 & 175 \\
\hline 85 & 24.51107 & 124.29218 & 320 & 210 & 120 \\
\hline
\end{tabular}




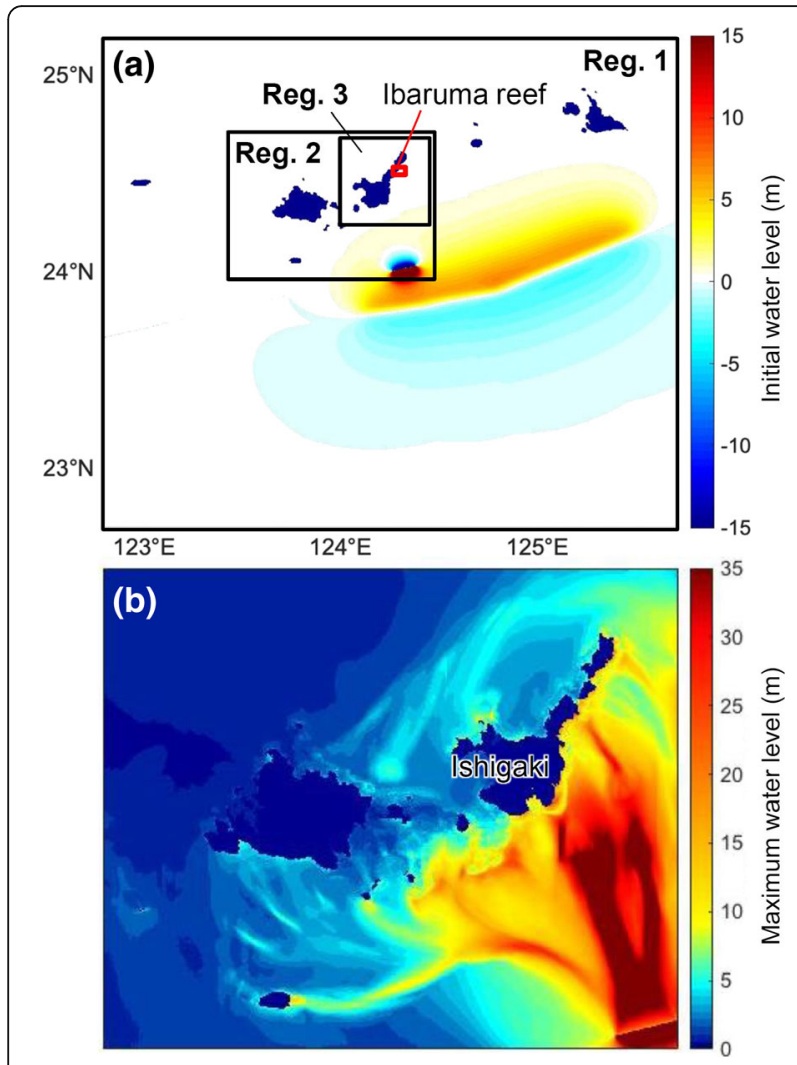

Fig. 3 a Computational domains for this study from region 1 to region 3. The initial water level of the 1771 Meiwa tsunami is also shown after Miyazawa et al. (2012) and Hisamatsu et al. (2014). b Maximum water level at $45 \mathrm{~min}$ after the tsunami in region 2 calculated in this study source models is not crucially important for our research. Therefore, this study applied the source model proposed by Hisamatsu et al. (2014) (Table 2), which is the updated version of the model described by Miyazawa et al. (2012), for the main discussion. Results obtained using the models of Imamura et al. (2008) and Nakamura (2009) are attached in the supplement file. As described above, the results are fundamentally the same in terms of local inundation and run-up at Ibaruma reef (Additional file 1: Figures S1-S6). Therefore, we do not advance our discussion using these models.

To evaluate the damage to corals from the tsunami, it is important to estimate the hydrodynamic force, which is expressed as the sum of the drag, inertia, and lift forces, acting on the corals (Massel and Done 1993; Madin and Connolly 2006; Imamura et al. 2008). We assumed living massive corals as ellipsoidal boulders and adopted numerical models for boulder transport by tsunami waves as proposed by Imamura et al. (2008). The model validity was well evaluated by subsequent studies (e.g., Goto et al. 2010c). For the calculation of the massive coral movement by the tsunami, we assumed average $(2.5 \times 1.9 \times 1.2 \mathrm{~m})$ and maximum $(9.0 \times 7.0 \times$ $3.9 \mathrm{~m}$ ) sizes of measured tsunami boulders (after Watanabe et al. 2016) to investigate the difference of tsunami impact against the coral size. The wet density of the boulders is assumed as $1.68 \mathrm{~g} / \mathrm{cm}^{3}$ (Goto et al. 2010b; Watanabe et al. 2016). The coefficients of static friction, dynamic friction, drag, and mass are respectively $0.68,0.65,1.05$, and 1.67 .

\section{Results}

\section{Field observation}

Living colonies of meter-long Porites spp. are observed in the shallow lagoon (Figs. $2 \mathrm{~b}$ and 4 ). Some of them have a microatoll shape. Tabular and branching corals are distributed mainly on the reef crest and the reef slope, although they are observed in rare cases in the shallow lagoon (Hongo and Kayanne 2009).

Whereas many massive corals exist in the Ibaruma reef, the distribution of meter-size living corals occurs only to a limited degree in the shallow lagoon (Fig. 4).

Table 2 A fault model used for this study

\begin{tabular}{llllllllll}
\hline Tsunami source & Latitude $(\mathrm{deg})$ & Longitude $(\mathrm{deg})$ & Depth $(\mathrm{km})$ & Length $(\mathrm{km})$ & Width $(\mathrm{km})$ & Dislocation $(\mathrm{m})$ & Strike $(\mathrm{deg})$ & Dip $(\mathrm{deg})$ & Rake $(\mathrm{deg})$ \\
\hline Fault 1 & 24.2018 & 125.5184 & 5 & 41 & 35 & 14 & 245 & 70 & 90 \\
Fault 2 & 24.0526 & 125.1497 & 5 & 40 & 35 & 14 & 246 & 70 & 90 \\
Fault 3 & 23.9100 & 124.8000 & 5 & 35 & 35 & 13 & 259 & 70 & 90 \\
Fault 4 & 23.8421 & 124.4576 & 5 & 36 & 35 & 14 & 261 & 70 & 90 \\
Landslide & 24.0036 & 124.2640 & 0.1 & 12 & 8 & 90 & 76 & 70 & 90 \\
\hline
\end{tabular}

The model was proposed by Miyazawa et al. (2012) and modified by Hisamatsu et al. (2014). The model is composed of four sub-faults with another fault that imitate the submarine landslide. Latitude and longitude of the fault model denote upper left corner of the rectangular fault 
The lagoon became deep from the beach toward the landward edge of the reef crest. Therefore, massive corals also tend to be large toward the deeper zone. The sea floor in the lagoon is covered by sand and coral rubble, with no exposure of the hard ground. Therefore, the massive corals in the lagoon are not attached to the bedrock but are instead located on the sandy sea bottom. This is an extremely important finding when considering the initial condition of corals for the tsunami numerical simulation.

The lengths of long and short axes of living massive corals show a positive correlation (Fig. 5), although their heights are weakly correlated with the long axis length: the heights are also constrained by the water depth because they cannot grow higher than the low tide level. The largest living massive coral observed in the Ibaruma reef is $6.5 \times 6.2 \times 1.9 \mathrm{~m}$ (no. 41 in Table 1). No coral is observed larger than this one in the studied region.

Goto et al. (2010b) studied the tsunami boulders deposited inside the lagoon and along the coast at the Ibaruma reef. According to their results, some of these boulders are also composed of massive Porites corals with the maximum of the Bari-ishi boulder (Fig. 2a, $9.0 \times 7.0 \times 3.9 \mathrm{~m}$ ). Similar to the living corals, some tsunami boulders show microatoll shape (Goto et al. 2010b). Not only are there coral boulders, but there are also some reef boulders. Different from the distribution of living corals, coral tsunami boulders tend to be observed in the landward half of the lagoon (shallower zone) and are mostly deposited along the shoreline (Fig. 4). Some large boulders are still deposited in the lagoon, but they had died. Part of them emerges during the low tide, indicating that they had certainly been moved landward from their original location.

\section{Numerical modeling}

Figure 3 shows the initial water level and the modeled maximum water level at $45 \mathrm{~min}$ after tsunami generation. The water level, which is high at the south to east coast of Ishigaki Island (ca. $28.2 \mathrm{~m}$ ), is consistent with estimated run-up heights from historical documents (ca.

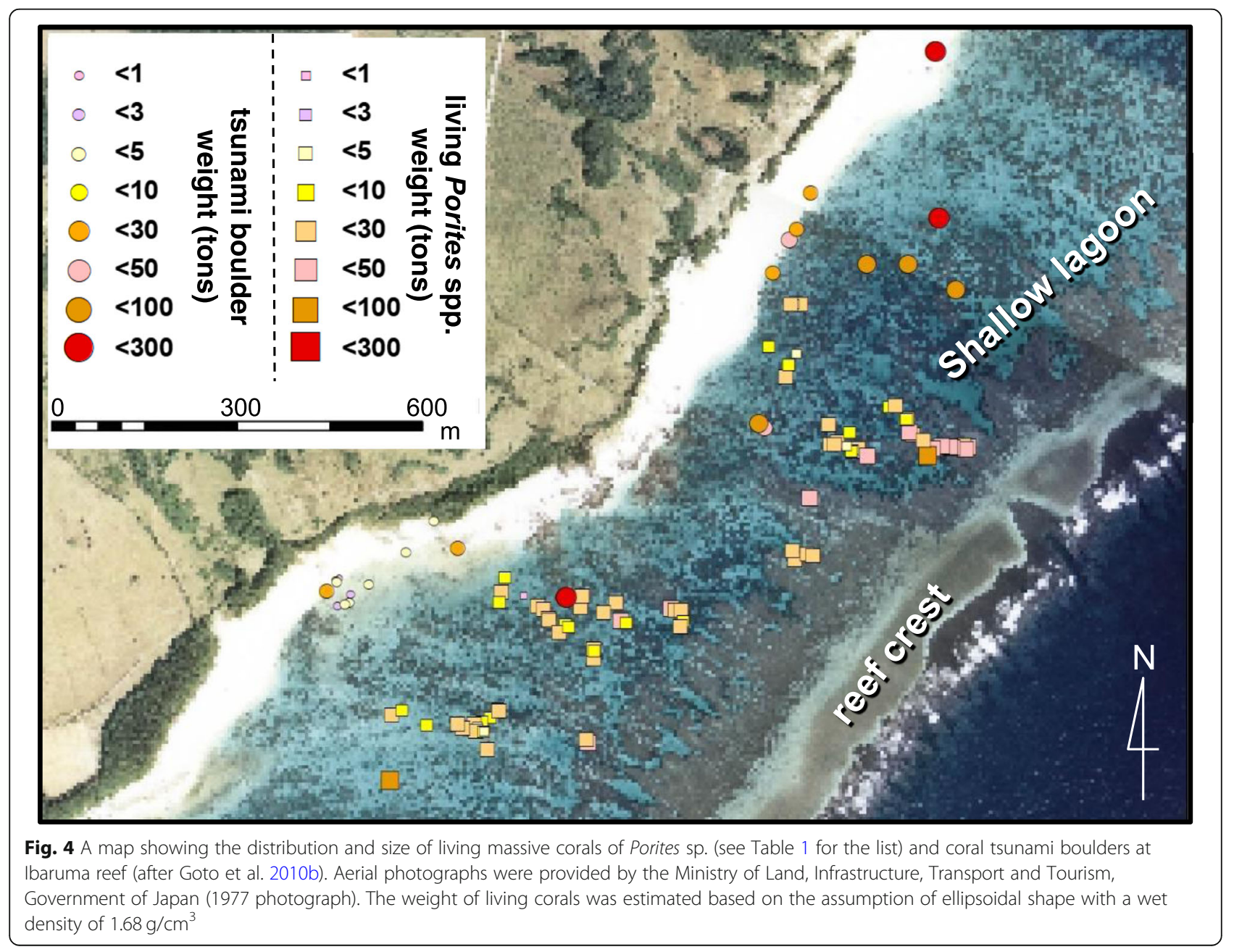




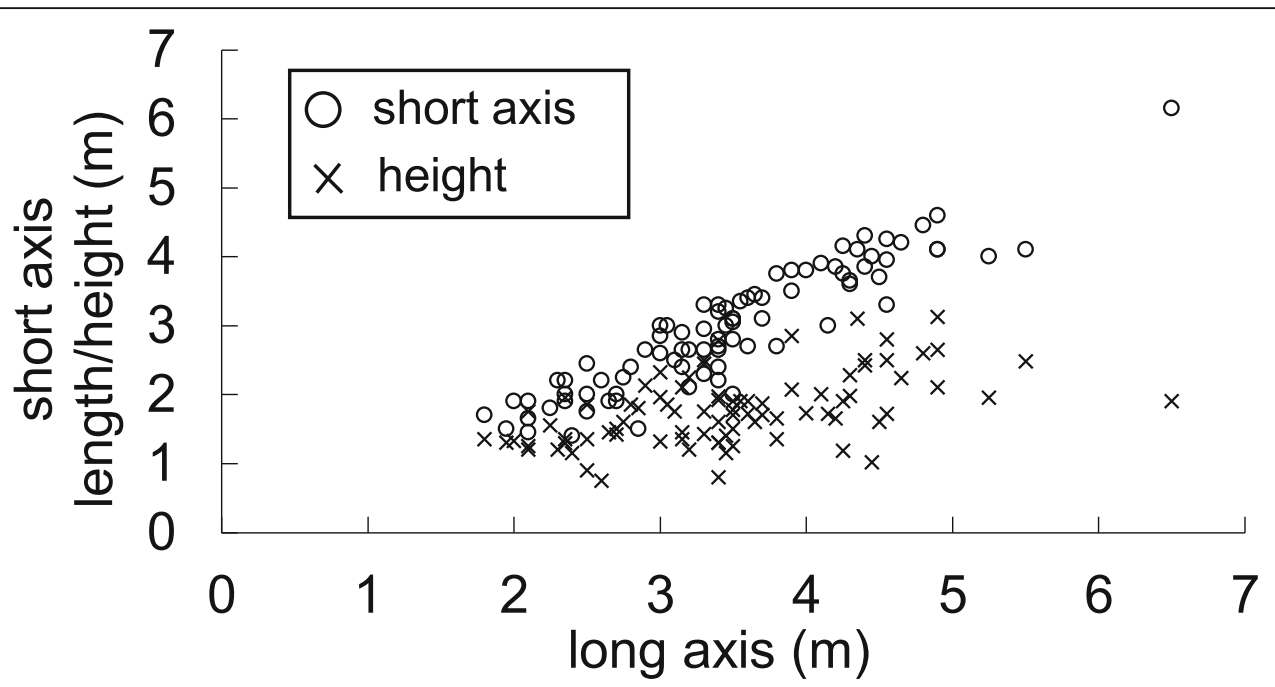

Fig. 5 A diagram showing the relation between long and short axes lengths and height of the living massive corals of Porites spp. See Table 1 for the list of original data

$30 \mathrm{~m}$, Goto et al. 2010a, 2012). The current velocity is higher at the reef slope rather than in the shallow lagoon (Fig. 6) because the very shallow fringing reef acts as a barrier and because the breaking point of the tsunami wave is far offshore of the reef edge. It is noteworthy that the maximum current velocity is reached at about $21.2 \mathrm{~m} / \mathrm{s}$ around the reef near the Ibaruma reef (Fig. 6). Such an extremely high current velocity is marked at the reef edge and channel (Fig. $6 \mathrm{~b}$ ). The maximum velocity is still high, even in the shallow lagoon of the east coast (Fig. 6b, c). In contrast to the east coast, the velocities are generally lower at the west coast than at the east coast (Fig. 6b).

Figure 7 shows the calculated initial and final stop positions of average and maximum sizes of corals moved by the 1771 Meiwa tsunami. The movement of average-size corals is well reproduced as they are cast ashore. However, the maximum boulder is moved a few hundred meters, although it is not shown to reach its present position. This underestimation by numerical results might be explained by two reasons. First, this region lacks a detailed description of tsunami run-up height: a study by Goto et al. (2012) estimated a wide range in run-up heights $(9.4-29.3 \mathrm{~m})$. Therefore, the constraint of the tsunami source model might have been insufficient locally, and tsunami hydrodynamic force could have been underestimated. Secondly, bathymetric data in the lagoon are not well reproduced because taking such measurements is difficult inside the lagoon. Therefore, a future update of the source model as well as bathymetry is required. Nevertheless, we infer that our results approximately reproduced the phenomena by which even a $9 \mathrm{~m}$ long huge massive coral could have been moved a few hundred meters. It could have emerged (dead) by the 1771 Meiwa tsunami.

\section{Discussion}

\section{Tsunami impact on the massive corals}

The lagoon in Ibaruma reef usually shows a calm condition, even during typhoon events, because the very shallow and wide reef crest protects the physical perturbation by the waves (Goto et al. 2010b; Hongo et al. 2012). In fact, massive corals could have grown to be very large (long axis of ca. $9 \mathrm{~m}$ ) with no physical disturbance during the typhoon-generated storm waves even if the massive corals had not been fixed on the ground. Hongo et al. (2012) suggested that a large storm wave can break far offshore of the reef edge and attenuate well before it reaches the shallow lagoon because the reef crest at the east coast of Ishigaki Island is well developed. This developed reef crest would be the main reason why such vulnerable massive corals in the shallow lagoon can survive the yearly typhoon impact over such a long period.

The 1771 Meiwa tsunami is the notable exception during at least the last 240 years, showing physical disturbance inside the lagoon of Ibaruma reef because of its very high current velocities acting on the massive corals $(<21.2 \mathrm{~m} / \mathrm{s})$. In fact, the largest Bari-ishi boulder could have been displaced easily by the 1771 Meiwa tsunami (Araoka et al. 2013). Moreover, this velocity is a few times higher than the observed current velocity of the recent tsunami events (Goto et al. 2007; Matsutomi and Okamoto 2010) including the 2004IOT-devastated areas such as the west coast of Sumatra Island, Indonesia (Prasetya et al. 2011), where minor to moderate coral damage was reported (Baird et al. 2005), the 2009 South Pacific tsunami 


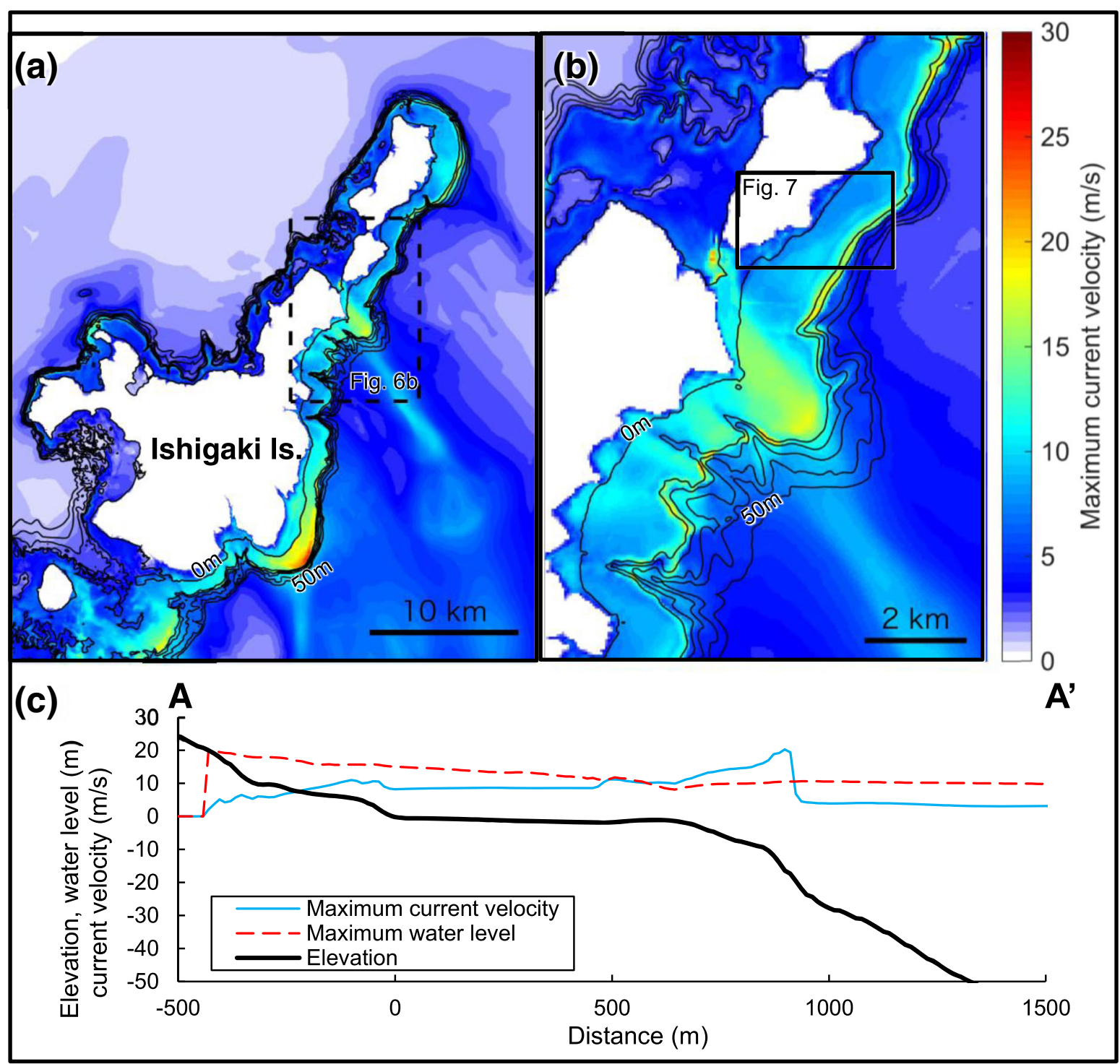

Fig. $\mathbf{6}$ a Numerical result for the absolute value of the maximum tsunami current velocity $(\mathrm{m} / \mathrm{s})$ around the Ishigaki Island and $\mathbf{b}$ around the Ibaruma reef. c Cross-sectional profiles of elevation $(\mathrm{m})$, maximum water level $(\mathrm{m})$, and maximum current velocity $(\mathrm{m} / \mathrm{s})$ at the $\mathrm{Ibaruma}$ reef. The transect location is depicted in Fig. 7a

(e.g., Dilmen et al. 2015) and the 2011 Tohoku-oki tsunami (Sugawara and Goto 2012).

Then, why is the tsunami velocity in the reef so high in case of the 1771 Meiwa tsunami? Recently, Kitamura et al. (2018b) examined the molluscan assemblages preserved within four ancient tsunami deposits, including 1771 Meiwa tsunami, in a trench located $4 \mathrm{~km}$ southwest of the study area. The authors concluded that the present-day shallow lagoon protected by reef crests has been present at least during the last 1200 years. Thus, high tsunami velocity is not explained by the absence of reef crests. First, this tsunami is exceedingly large locally, even if compared to recent large tsunami events. The maximum run-up height is estimated as approx. $30 \mathrm{~m}$ (Goto et al. 2010a) and is lower than the approx. $\sim 40-50 \mathrm{~m}$ run-ups of the 2004IOT (Lavigne et al. 2009) and the 2011 Tohoku-oki tsunami (Mori et al. 2012). However, the maximum run-up height of the 1771 Meiwa tsunami was recorded at the flat coastal area with the protection of the coast by the approx. $1.5 \mathrm{~km}$-wide reef (Goto et al. 2010a), whereas high run-up heights of the 2004IOT and the 2011 Tohoku-oki tsunami were recorded in narrow valleys and bays where tsunamis could have been focused and could have thereby reached so high. Therefore, the impact of the 1771 Meiwa tsunami on the reef could have been much stronger than the other recent large tsunamis. Secondly, the fault width, which affects the tsunami wave length, of the recent 

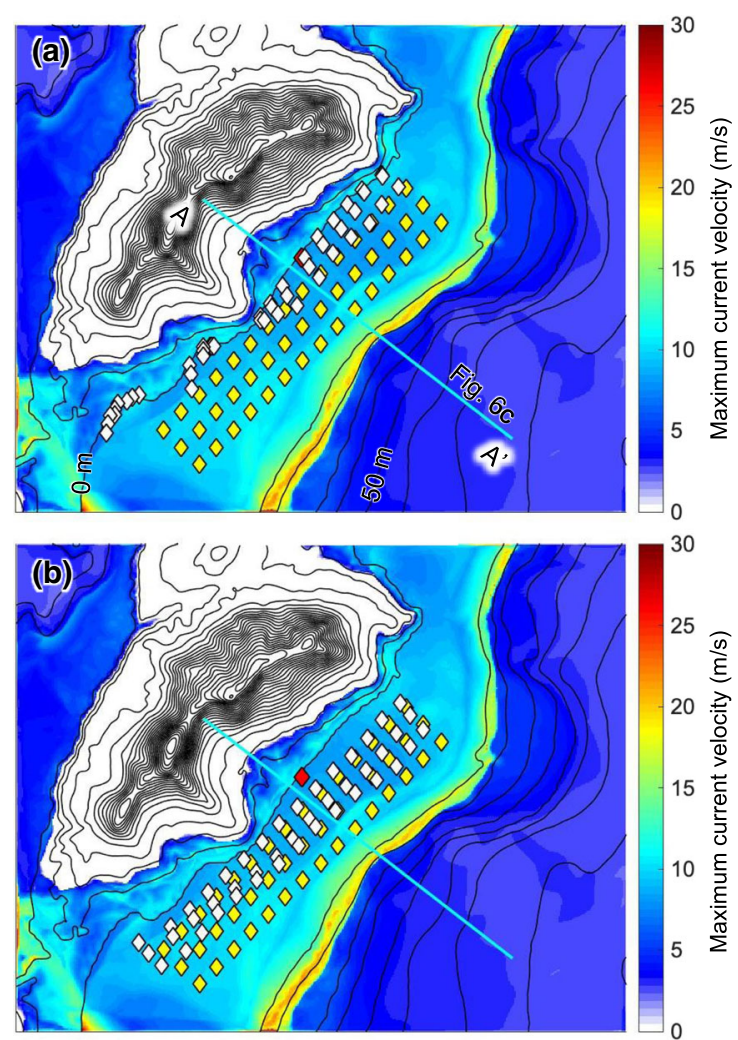

Fig. 7 Numerical results of coral transport by the 1771 Meiwa tsunami in region 4. a Average size boulder. b The largest boulder. Yellow, white, and red diamonds respectively denote original location, final stop position, and present location of Bari-ishi boulder. The line in $\mathbf{a}$ is the transect line in Fig. $6 \mathrm{c}$

tsunami such as the 2011 Tohoku-oki tsunami is estimated as about $100 \mathrm{~km}$ (e.g., Imamura et al. 2012), whereas that of the 1771 Meiwa tsunami is estimated as less than $35 \mathrm{~km}$ (Table 2, Additional file 2, Imamura et al. 2008; Nakamura 2009; Miyazawa et al. 2012). If the wave length or period of the tsunami becomes short, the vertical variation of water level becomes faster; thus, horizontal current velocity also becomes faster. Indeed, some researchers stated that a tsunami with a shorter wave length usually generates a faster current for a given wave height (e.g., Gusman et al. 2012). Moreover, to explain a $30 \mathrm{~m}$ high run-up at the very flat and reef-protected coast, the initial maximum water levels must also be very high (Fig. 3a, Miyazawa et al. 2012). Therefore, the 1771 Meiwa tsunami can be characterized as having a short wave period with exceedingly large wave height, which indicates that the wave has a very steep shape. Such a wave can generate extremely high velocity at the reef after wave breaking.

No massive coral, living or dead, is larger than the Bari-ishi boulder in the shallow lagoon of the east coast of Ishigaki Island. Displacement of the largest Bari-ishi boulder by the 1771 Meiwa tsunami suggests that the massive corals of Porites spp. smaller than the boulder that was in the shallow lagoon before the 1771 Meiwa tsunami should have been displaced easily on land or resettled somewhere in the shallow lagoon by the tsunami. This supposition is well confirmed: small boulders are easily cast ashore by the tsunami (Fig. 7a). If this is the case, then massive corals of Porites spp. in the shallow lagoon of the Ishigaki Island were once fully devastated by the 1771 Meiwa tsunami: they subsequently restarted the growth after the tsunami. It is noteworthy that massive corals are not attached to the ground but merely located on the sandy ground. This would be very important evidence suggesting that many large massive corals were deposited by the 1771 Meiwa tsunami because they were movable.

This hypothesis is testable based on the size of the presently living massive corals. Massive corals of Porites spp. showed a high average growth rate of $7-20 \mathrm{~mm} /$ year at Ishigaki Island (Mitsuguchi et al. 1996; Tsunoda et al. 2006; Suzuki et al. 2008; Shimamura et al. 2008; Araoka et al. 2010). Among them, the study site by Araoka et al. (2010), where the average growth rate of Porites sp. is about $13.5 \mathrm{~mm}$ /year (about $10-20 \mathrm{~mm} /$ year, $\mathrm{D}$. Araoka, personal communication), is the closest location to our site. In addition, Araoka et al. (2013) 
estimated the creation of the Bari-ishi boulder as AD 1227-1317 $( \pm 1 \sigma)$ based on ${ }^{14} \mathrm{C}$ age measurements. The coral is dead by the time of the 1771 Meiwa tsunami. Therefore, this boulder grew up to $9 \mathrm{~m}$ in diameter during 454-544 years. Consequently, the growth rate can be estimated as about $8.3-9.9 \mathrm{~mm} /$ year $(4.5 \mathrm{~m}$ in radius divided by $454-544)$, which is well consistent with the growth rate estimated from Araoka et al. (2010).

Today, some 240 years have passed since the tsunami for which we conducted the field survey in 2011. Therefore, the size of the massive corals can be expected to have reached up to about $4.0-6.5 \mathrm{~m}$ in diameter $(8.3-13.5(\mathrm{~mm} /$ year $) \times 240$ (years $) \times 2$ (to be diameter) . Considering the variation of the growth rate depending on the local factors, we infer that this estimated possible maximum size is well consistent with the observed maximum size of the living massive corals in the shallow lagoon of the Ibaruma reef, which is less than $6.5 \mathrm{~m}$ (Table 1, Fig. 5).

Some Porites boulders that had been transported by the tsunami have also been redeposited in the shallow lagoon (Fig. 4, Suzuki et al. 2008; Goto et al. 2010a). They could have survived the tsunami if the conditions of the shallow lagoon soon after the tsunami were suitable for coral growth. However, the absence of living corals larger than $6.5 \mathrm{~m}$ suggests that no such corals exist. Consequently, even massive corals that were transported by the tsunami but which were still located in the shallow lagoon might have died soon after the tsunami. This fact is probably explained by the indirect effect of the tsunami on the corals. For example, sand or coral fragments might have covered the massive corals. Impact of the sand and coral fragments flowing in the tsunami current on the living corals would have been another damaging influence on the living corals. Terrestrial reddish soil, which usually affects the coral habitability (Fortes 2001), might have been deposited by the backwash in great amounts in the shallow lagoon.

\section{Tsunami impact on tabular and branching corals}

Damage to tabular and branching corals by the tsunami is far more difficult to evaluate than that to the massive corals because of the corals' complex structures and their habitability. According to numerical modeling conducted by Kawamata et al. (2009), the coral damage is generally proportional to the tsunami current velocity: approx. 50\% coral damage was generated at Similan Island in Thailand by the 2004IOT when the maximum current velocity of the tsunami exceeded about $5 \mathrm{~m} / \mathrm{s}$. Hongo et al. (2012) also suggested that tabular corals might be damaged by typhoon-generated storm waves with approx. $6 \mathrm{~m} / \mathrm{s}$ current velocity. It is particularly important to note that our estimated maximum current velocity generated by the 1771 Meiwa tsunami at the Ibaruma reef is a few times higher than these estimates. Therefore, it is conservative to estimate that many tabular or branching corals at the east coast of Ishigaki Island were physically damaged by the 1771 Meiwa tsunami.

Hongo et al. (2012) revealed that larger tabular corals are more vulnerable to wave impact because they can be affected by larger wave force attributable to their shapes. This result in turn suggests that smaller tabular corals might have some chance of surviving the tsunami impact. In fact, Reyes et al. (2015) reported limited damage to corals after super typhoon Haiyan on 2013.

Tabular and branching corals are far smaller than the massive corals. Moreover, these corals are selectively distributed mainly on the reef crest and the reef slope, where the storm wave impact is strong (Hongo et al. 2012). Therefore, they might have been damaged repeatedly and restarted growth in a short return period by large typhoons every few to a few tens of years (Hongo et al. 2012). Therefore, the tsunami impact might have been one such destructive events for them and might not have been remarkable, as in the case of massive corals.

\section{Conclusions}

It is usually considered that local conditions (e.g., salinity, water temperature, frequency, and magnitude of storm wave impact) should have affected the growth history of corals and coral reefs (Montaggioni and Braithwaite 2009). However, catastrophic destruction of coral by the tsunami would also have been one important factor affecting the coral growth at Ishigaki Island because historical and geological evidence indicates that small and large tsunamis in the past frequently struck eastward of the island at 150 to 400 or 600-year intervals (e.g., Araoka et al. 2013; Ando et al. 2018). If this is the case, then coral habitability at the east coast of Ishigaki Island might have been repeatedly reset and restarted to grow every few hundred years. This idea can be tested further in future work to compare the differences of the coral characteristics, size, and diversity at the west coast of Ishigaki Island, where damage from the paleotsunamis is expected to have been minor (Goto et al. 2010a).

Our results further suggest that similar catastrophic damage of corals by tsunamis can be expected at locations where remarkably large near-field tsunamis might have been generated, such as tropical islands in the Pacific Ocean (e.g., Frohlich et al. 2009). Not only the tsunami energy and local bathymetry but also coral characteristics (e.g., whether massive corals attached to the ground or not) would be very important factors of coral damage. At the coral reefs of high tsunami-risk countries, the catastrophic destruction of corals by large tsunamis should be 
considered when assessing their growth history because tsunamis can radically change the coral habitability, reef geomorphology, and the environment. Living massive corals in the Ibaruma reef are not attached to the ground. Therefore, they are very vulnerable to large tsunami waves. The risk can be very high because 248 years have passed since the 1771 Meiwa tsunami. It is almost "on time" if we consider the tsunami recurrence of 150-400 years (Araoka et al. 2013). If the size of an incident tsunami is equivalent to the 1771 Meiwa tsunami, then presently living massive corals would be entirely devastated because they are still small $(<6.5 \mathrm{~m})$. Therefore, environmental risk assessment of coral reefs should be performed, beyond considerations of damage to humanity and infrastructure.

Importantly, corals on the east coast of Ishigaki Island are now characterized by high species diversity (Veron 1992). Although it is uncertain how long environmental stress continued for corals after the tsunami, we infer that its effects are not permanent. Potentially, large tsunamis can act as important agents to alter coral diversity in the lagoon because all corals have a chance to occupy the niche of the barren reef as they contemporaneously start to grow after a large tsunami.

\section{Additional files}

Additional file 1: Figure S1. (a) Initial water level of the tsunami source model proposed by Imamura et al. (2008). (b) Maximum water level at 45 min after the tsunami in region 2. Figure S2. (a) Initial water level of the tsunami source model proposed by Nakamura (2009). (b) Maximum water level at 60 min after the tsunami in region 2. Figure S3. (a) Numerical result for the absolute value of the maximum tsunami current velocity $(\mathrm{m} / \mathrm{s})$ around the Ishigaki Island and (b) around the Ibaruma reef using the model proposed by Imamura et al. (2008). Figure S4. Numerical results of coral transport by the 1771 Meiwa tsunami using the model proposed by Imamura et al. (2008): (a) average size boulder and (b) the largest boulder. Yellow, green, and red diamonds respectively denote the original location, final stop position, and present location of Bari-ishi boulder. Figure S5. (a) Numerical result for the absolute value of the maximum tsunami current velocity $(\mathrm{m} / \mathrm{s})$ around the Ishigaki Island and (b) around the Ibaruma reef using the model proposed by Nakamura (2009). Figure S6. Numerical results of coral transport by the 1771 Meiwa tsunami using the model proposed by Nakamura (2009): (a) average size boulder and (b) the largest boulder. Yellow, green, and red diamonds respectively denote the original location, final stop position, and present location of Bari-ishi boulder. (PDF 1163 kb)

Additional file 2: Table S1. Fault models proposed by Nakamura (2009) and Imamura et al. (2001). (XLSX 9 kb)

\section{Abbreviations}

2004IOT: 2004 Indian Ocean tsunami; PMBC: Phuket Marine Biological Center

\section{Acknowledgements}

We appreciate $\mathrm{H}$. Kawamata and Y. Suda for their support during field survey. Bathymetric data for numerical modeling were provided by Okinawa Prefecture. The editor J. Matsumoto and anonymous reviewers provide valuable comments on improving our manuscript.

\section{Funding}

This work is supported by JSPS KAKENHI Grant Number 22241042.
Availability of data and materials

Please contact author for data requests.

\section{Authors' contributions}

KG proposed the topic and conceived and designed the study. $\mathrm{KG}$ and $\mathrm{CH}$ conducted the field survey. MW, KM, and $\mathrm{AH}$ conducted the numerical modeling of tsunami and boulder transport. $\mathrm{CH}$ collaborated with the corresponding author in the construction of the manuscript. All authors read and approved the final manuscript.

\section{Authors' information}

KM and AH are, respectively, now at Tokyo Gas Co., Ltd. and Penta Ocean Construction Co., Ltd

\section{Competing interests}

The authors declare that they have no competing interests.

\section{Publisher's Note}

Springer Nature remains neutral with regard to jurisdictional claims in published maps and institutional affiliations.

\section{Author details}

${ }^{1}$ International Research Institute of Disaster Science, Tohoku University, Aoba 468-1 Aramaki, Aoba-ku, Sendai 980-0845, Japan. ²Department of Chemistry, Biology, and Marine Science, University of the Ryukyus, 1 Senbaru, Nishihara, Okinawa 903-0213, Japan. ${ }^{3}$ School of Engineering, Tohoku University, Aoba 468-1 Aramaki, Aoba-ku, Sendai 980-0845, Japan.

Received: 3 August 2018 Accepted: 21 January 2019

Published online: 13 February 2019

\section{References}

Ando M, Kitamura A, Tu Y, Ohashi Y, Imai T, Nakamura M, Ikuta R, Miyairi Y, Yokoyama Y, Shishikura M (2018) Source of high tsunamis along the southernmost Ryukyu Trench inferred from tsunami stratigraphy. Tectonophysics 722:265-276

Arai R, Takahashi T, Kodaira S, Kaiho Y, Nakanishi A, Fujie G, Nakamura Y Yamamoto Y, Ishihara Y, Miura S, Kaneda Y (2016) Structure of the tsunamigenic plate boundary and low-frequency earthquakes in the southern Ryukyu Trench. Nature Comm 7:12255. https://doi.org/10.1038/ ncomms 12255

Araoka D, Inoue M, Suzuki A, Yokoyama Y, Edwards RL, Cheng H, Matsuzaki H, Kan H, Shikazono N, Kawahata H (2010) Historic 1771 Meiwa tsunami confirmed by high-resolution U/Th dating of massive Porites coral boulders at Ishigaki Island in the Ryukyus, Japan. Geochem Geophys Geosyst 11 Q06014. https://doi.org/10.1029/2009GC002893

Araoka D, Yokoyama Y, Suzuki A, Goto K, Miyagi K, Miyazawa K, Matsuzaki H, Kawahata H (2013) Tsunami recurrence revealed by Porites coral boulders in the southern Ryukyu Islands, Japan. Geology 41:919-922

Atwater BF, ten Brink USUS, Cescon AL, Feuillet N, Fuentes Z, Halley RB, Nuñez C, Reinhardt EG, Roger JH, Sawai Y, Spiske M, Tuttle MP, Wei Y, Weil-Accardo J (2017) Extreme waves in the British Virgin Islands during the last centuries before 1500 CE. Geosphere 13(2):301-368

Baird AH, Campbell SJ, Anggoro AW, Ardiwijaya RL, Fadi N, Herdiana Y, Kartawijaya T, Mahyiddin D, Mukminin A, Pardede ST, Pratchett MS, Rudi E, Siregar AM (2005) Achenese reef in the wake of the Asian tsunami. Curr Biol 15:1928-1930

Chavanich S, Viyakarn V, Sojisuporn P, Siripong A, Menasveta P (2008) Patterns of coral damage associated with the 2004 Indian Ocean tsunami at Mu Ko Similan Marine National Park, Thailand. J Nat Hist 42:177-187

Dilmen DI, Titov W, Roe G (2015) Evaluation of the relationship between coral damage and tsunami dynamics. Case study: 2009 Samoa tsunami. Pure Appl Geophys 172:3557-3572

Fortes M (2001) The effect of siltation on tropical coastal ecosystems, in oceanographic processes of coral reefs: physical and biological links in the Great Barrier Reef. CRC Press, Florida

Frohlich C, Hornbach MJ, Taylor FW, Shen CC, Moala A, Morton AE, Kruger J (2009) Huge erratic boulders in Tonga deposited by a prehistoric tsunami. Geology 37:131-134 
Goto C, Ogawa Y, Shuto N, Imamura F (1997) IUGG/IOC Time Project, numerical method of tsunami simulation with the Leap-Frog scheme. IOC Manuals and Guides, UNESCO, Paris

Goto K, Chavanich SA, Imamura F, Kunthasap P, Matsui T, Minoura K, Sugawara D, Yanagisawa $H$ (2007) Distribution, origin and transport process of boulders deposited by the 2004 Indian Ocean tsunami at Pakarang Cape, Thailand. Sediment Geol 202:821-837

Goto K, Imamura F (2009) A simple numerical model for the damage of corals by tsunami. In: Davin TB, Barnnet AP (eds) Coral reefs: biology, threats and restoration. NOVA Publisher, Hauppauge, pp 239-249

Goto K, Kawana T, Imamura F (2010a) Historical and geological evidence of boulders deposited by tsunamis, southern Ryukyu Islands, Japan. Earth-Sci Rev 102:77-99

Goto K, Miyagi K, Imamura F (2013) Localized tsunamigenic earthquakes inferred from preferential distribution of coastal boulders on Ryukyu Islands, Japan. Geology 41:1139-1142

Goto K, Miyagi K, Kawamata H, Imamura F (2010b) Discrimination of boulders deposited by tsunamis and storm waves at Ishigaki Island, Japan. Mar Geol 269:34-45

Goto K, Miyazawa K, Adaniya A, Kakihana S, Kugai M, Shimabukuro A Shimabukuro N, Masaki Y, Matsushima S, Miyagi K (2012) Reevaluation of the run-up height of the 1771 Meiwa tsunami II - the Sakishima Islands. Res Rep Tsunami Eng 29:129-146

Goto K, Okada K, Imamura F (2010c) Numerical analysis of boulder transport by the 2004 Indian Ocean tsunami at Pakarang Cape, Thailand. Mar Geol 268:97-105

Gusman AR, Tanioka Y, Takahashi T (2012) Numerical experiment and a case study of sediment transport simulation of the 2004 Indian Ocean tsunami in Lhok Nga, Banda Aceh, Indonesia. Earth Planet Sp 64:3. https://doi.org/10. 5047/eps.2011.10.009

Hisamatsu A, Goto K, Imamura F (2014) Local paleo-tsunami size evaluation using numerical modeling for boulder transport at Ishigaki Island, Japan. Episodes $37: 265-276$

Hongo C, Kawamata H, Goto K (2012) Catastrophic impact of typhoon waves on coral communities in the Ryukyu Islands under global warming. J Geophys Res 117:G02029. https://doi.org/10.1029/2011JG001902

Hongo C, Kayanne H (2009) Holocene coral reef development under windward and leeward locations at Ishigaki Island, Ryukyu Islands, Japan. Sediment Geol 214:62-73

Hongo C, Kayanne H (2010) Relation between species diversity and reef growth in the Holocene at Ishigaki Island, Pacific Ocean. Sediment Geol 223:86-99

Hongo C, Kurihara H, Golbuu Y (2018) Coral boulders on Melekeok reef in the Palau Islands: an indicator of wave activity associated with tropical cyclones. Mar Geol 399:14-22

Hsu SK, Yeh YC, Sibuet JC, Doo WB, Tsai CH (2013) A mega-splay fault system and tsunami hazard in the southern Ryukyu subduction zone. Earth Planet Sci Lett 362:99-107

Imamura F, Yoshida I, Moore A (2001) Numerical study of the 1771 Meiwa tsunami at Ishigaki Island, Okinawa and the movement of the tsunami stones. P Coast Eng JSCE 48:346-350

Imamura F, Goto K, Ohkubo S (2008) A numerical model for the transport of a boulder by tsunami. J Geophys Res 113:C01008. https://doi.org/10.1029/ 2007JC004170

Imamura F, Koshimura S, Oie T, Mabuchi Y, Murashima Y, (2012) Tsunami simulation for the 2011 off the Pacific coast of Tohoku earthquake (Tohoku University model ver. 1.2). Available at http://www.tsunami.civil. tohoku.ac.jp/hokusai3/J/events/tohoku_2011/model/dcrc_ver1.2.pdf. Accessed 3 July 2018

Kawamata H, Goto K, Imamura F (2009) Numerical evaluation of coral damage by the 2004 Indian Ocean tsunami at Similan Islands, Thailand. P Coast Eng JSCE B2(65):331-335

Kawana T, Nakata K (1994) Timing of Late Holocene tsunamis originated around the southern Ryukyu Islands, Japan, deduced from coralline tsunami deposits. J Geograph Japan 103:352-376

Kitamura A, Ito M, Ikuta R, Ikeda M (2018b) Using molluscan assemblages from paleotsunami deposits to evaluate the influence of topography on the magnitude of late Holocene mega-tsunamis on Ishigaki Island, Japan. Prog Earth Planet Sci 5:41

Kitamura A, Ito M, Sakai S, Yokoyama Y, Miyairi Y (2018a) Identification of tsunami deposits using a combination of radiometric dating and oxygen-isotope profiles of articulated bivalves. Mar Geol 403:57-61

Kotani M, Imamura F, Shuto N (1998) Tsunami run-up simulation and damage estimation by using GIS. P Coast Eng JSCE 45:356-360
Lavigne F, Paris R, Grancher D, Wassmer P, Brunstein D, Vautier F, Leone F, Flohic F, de Coster B, Gunawan T, Gomez C, Setiawan A, Cahyadi R, Fachrizal (2009) Tsunamis as geomorphic crises: lessons from the December 26, 2004 tsunami in Lhok Nga, West Banda Aceh (Sumatra, Indonesia). Pure Appl Geophys 166(1-2):259-281

Madin JS, Connolly SR (2006) Ecological consequences of major hydrodynamic disturbances on coral reefs. Nature 444:477-480

Massel SR, Done TJ (1993) Effects of cyclone waves on massive coral assemblages on the Great Barrier Reef: meteorology, hydrodynamics and demography. Coral Reefs 12:153-166

Matsutomi H, Okamoto K (2010) Inundation flow velocity of tsunami on land. Island Arc 19:443-457

McAdoo B, Ah-Leong JS, Bell L, Ifopo P, Ward J, Lovell E, Skelton P (2011) Coral reefs as buffers during the 2009 South Pacific tsunami, Upolu Island, Samoa. Earth-Sci Rev 107:147-155

Ministry of the Environment and the Japanese Coral Reef Society (2004) Coral reefs of Japan. Ministry of the Environment, Tokyo

Mitsuguchi T, Matsumoto E, Abe O, Uchida T, Isdale PJ (1996) Mg/Ca thermometry in coral skeletons. Science 274:961-963

Miyazawa K, Goto K, Imamura F (2012) Re-evaluation of the 1771 Meiwa tsunam source model, southern Ryukyu Islands, Japan. In: Yamada Y, Kawamura K, Ikehara K, Ogawa Y, Urgeles R, Mosher D, Chaytor J, Strasser M (eds) Advances in natural and technological hazards research, Submarine mass movements and their consequences, vol 31. Springer, Heidelberg, pp 497-506

Montaggioni LF, Braithwaite CJR (2009) Quaternary coral reef systems. Elsevier, Amsterdam

Mori N, Takahashi T, The 2011 Tohoku Earthquake Tsunami Joint Survey Group (2012) Nationwide post event survey and analysis of the 2011 Tohoku earthquake tsunami. Coast Eng J 54(1):1250001. https://doi.org/10.1142/ S0578563412500015

Morri C, Montefalcone M, Lasagna R, Gatti G, Rovere A, Parravicini V, Baldelli G, Colantoni P, Bianchi CN (2015) Through bleaching and tsunami: coral reef recovery in the Maldives. Mar Pollut Bull 98:188-200

Nakamura M (2009) Fault model of the 1771 Yaeyama earthquake along the Ryukyu Trench estimated from the devastating tsunami. Geophys Res Lett 36:L19307. https://doi.org/10.1029/2009GL039730

Okamura Y, Nishizawa A, Fujii Y, Yanagisawa H (2018) Accretionary prism collapse: a new hypothesis on the source of the 1771 giant tsunami in the Ryukyu Arc, SW Japan. Sci Rep 8:13620. https://doi.org/10.1038/s41598-01831956-8

Phuket Marine Biological Center (PMBC) (2005) Rapid assessment of the tsunami impact on marine resources in the Andaman Sea, Thailand. Chulalongkorn University Printing House, Bangkok

Prasetya G, Borrero J, de Lange W, Black K, Healy T (2011) Modeling of inundation dynamics on Banda Aceh, Indonesia during the great Sumatra tsunamis December 26, 2004. Nat Hazards 58:1029-1055

Puotinen M, Maynard JA, Beeden R, Radford B, Williams GJ (2016) A robust operational model for predicting where tropical cyclone waves damage coral reefs. Sci Rep 6:26009. https://doi.org/10.1038/srep26009

Ramos NT, Maxwell KV, Tsutsumi H, Chou YC, Duan F, Shen CC, Satake K (2017) Occurrence of 1 ka-old corals on an uplifted reef terrace in West Luzon, Philippines: implications for a prehistoric extreme wave event in the South China Sea region. Geosci Lett 4:12

Reyes M, Engel M, May SM, Brill D, Brueckner H (2015) Life and death after super typhoon Haiyan. Coral Reefs 34:419

Rixhon G, May SM, Engel M, Mechernich S, Schroeder-Ritzrau A, Frank N, Fohlmeister J, Boulvain F, Dunai T, Brückner H (2018) Multiple dating approach $\left({ }^{14} \mathrm{C},{ }^{230} \mathrm{Th} / \mathrm{U}\right.$ and $\left.{ }^{36} \mathrm{Cl}\right)$ of tsunami-transported reef-top boulders on Bonaire (Leeward Antilles) - current achievements and challenges. Mar Geol 396:100-113

Shimamura M, Hyeong K, Yoo CM, Watanabe T, Irino T, Jung HS (2008) High resolution stable isotope record of sclreractinian corals near Ishigaki Island: their implication as a potential paleoclimatic recorder in middle latitude regions. Geosci J 12:25-31

Sugawara D, Goto K (2012) Numerical modelling for the 2011 Tohoku-oki tsunami at offshore and onshore of Sendai Plain, Japan. Sediment Geol 282: 110-123

Suzuki A, Yokoyama Y, Kan H, Minoshima K, Matsuzaki H, Hamanaka N, Kawahata $H$ (2008) Identification of 1771 Meiwa tsunami deposits using a combination of radiocarbon dating and oxygen isotope microprofiling of emerged massive Porites boulders. Quarter Geochronol 3:226-234 
Tsunoda T, Kawahata H, Suzuki A, Mimoshima K, Shikazono N (2006) Winter sea surface temperature variations based on coral oxygen isotope record from Ishigaki Island, the Ryukyus, Japan and its relationship to 1988/1989 climate regime shift. Chikyukagaku 40:301-311

Veron JEN (1992) Conservation of biodiversity: a critical time for the hermatypic corals of Japan. Coral Reefs 11:13-21

Watanabe M, Goto K, Imamura F, Hongo C (2016) Numerical identification of tsunami boulders and estimation of local tsunami size at Ibaruma reef of Ishigaki Island, Japan. Island Arc 25:316-332

Witt DL, Young YL, Yim SC (2011) Field investigation of tsunami impact on coral reefs and coastal sandy slopes. Mar Geol 289:159-163

\section{Submit your manuscript to a SpringerOpen ${ }^{\odot}$} journal and benefit from:

- Convenient online submission

Rigorous peer review

- Open access: articles freely available online

High visibility within the field

- Retaining the copyright to your article

Submit your next manuscript at $\boldsymbol{\nabla}$ springeropen.com 